\title{
Efektivitas Pengaruh Konseling Kelompok Terhadap Efikasi Diri Siswa
}

\author{
Effectiveness Group Counseling Effect of Self Efficacy Students
}

\author{
Sri Widaryati \\ Universitas Ahmad Dahlan \\ Email: sriwidaryati@ymail.com
}

\begin{abstract}
Abstrak
Tujuan dari penelitian ini adalah untuk mengetahui pengaruh konseling kelompok terhadap efikasi diri siswa kelas X SMA N 1 Pengasih Kulon Progo. Penelitian ini termasuk penelitian eksperimen dengan metode pre-test dan post-test eksperimen. Pengambilan subyek dalam penelitian ini melalui hasil screening skala efikasi diri dan sampel yang diambil sebanyak 16 siswa yang selanjutnya dibagi menjadi kelompok eksperimen dan kelompok kontrol berdasarkan random assigment. Teknik pengumpulan data menggunakan instrumen skala efikasi diri yang sebelum digunakan diuji terlebih dahulu validitas dan reliabilitasnya. Teknik analisis data yang digunakan adalah independen t-test yang sebelumnya diuji prasyarat, yaitu normalitas dan homogenitas. Hasil analisis data menunjukkan bahwa data gain skor kelas eksperimen dan kontrol memenuhi uji prasyarat yaitu normal dan homogen, selanjutnya dilakukan uji independent $t$ test. Hasil uji independent $t$ test gain skor efikasi diri menunjukkan nilai p-value sebesar 0,000 yang berarti lebih kecil dari taraf signifikansi $(0,01)$. Berdasarkan hasil tersebut dapat disimpulkan bahwa terdapat pengaruh konseling kelompok yang sangat signifikan terhadap efikasi diri siswa kelas X SMA N 1 Pengasih Kulon Progo.
\end{abstract}

Kata kunci: konseling kelompok, efikasi diri.

\begin{abstract}
The aim of this study was to determine the effect on self-efficacy group counseling class $X$ Senior High School 1 Compassionate Kulon Progo. This study includes research experiment with methods of pre-test and post-test experiment. Capturing subjects in this study through self-efficacy scale screening results and samples taken as many as 16 students were further divided into an experimental group and the control group based on random assigment. Data collection techniques using self-efficacy scale instruments before use tested first for validity and reliability. Data analysis technique used was the independent t-test were previously tested prerequisites, namely normality and homogeneity. The result showed that the gain of the data and the control experimental class scores meet the prerequisite test is normal and homogeneous, then performed an independent test $t$ test. Test results of independent $t$ test gain self-efficacy scores indicate p-value of 0.000 which is smaller than the significance level (0.01). Based on these results it can be concluded that there are significant very significant group counseling on self-efficacy class $X$ Senior High School 1 Compassionate Kulon Progo.
\end{abstract}

Keywords: counseling group, self efficacy.

\section{Pendahuluan}

Pembangunan manusia Indonesia yang bermutu saat ini sangat dibutuhkan, seiring dengan kemajuan berpikir dan kesadaran manusia akan diri dan dunianya. Pendukung utama tercapainya sasaran pembangunan manusia Indonesia yang bermutu adalah pendidikan yang bermutu.

Surya (2004) mengemukakan bahwa pelajar yang efektif adalah mereka yang mampu melakukan kegiatan belajar dengan mendapatkan hasil sebaik-baiknya dan dapat diterapkan dalam berbagai aspek 
kehidupannya. Penilaian seseorang terhadap kemampuan diri yang dimiliki mempunyai peran yang sangat penting dalam proses perkembangan individu. Zimmerman (2009) mengemukakan bahwa efikasi diri berpengaruh terhadap pencapaian akademik dan mempengaruhi keberhasilan belajar siswa. Hasil penelitian yang dilakukan oleh Caroll, dkk (2009) menunjukkan bahwa efikasi diri memiliki hubungan yang positif dengan prestasi akademik. Hasil penelitian Susilowati (2009) juga menyimpulkan bahwa ada hubungan yang positif antara efikasi diri dengan prestasi belajar. Efikasi diri merupakan keyakinan terhadap kemampuan yang dimiliki individu dan keyakinan penyelesaian tugas-tugas yang dihadapi untuk mengatasi rintangan dan mencapai tujuan yang diharapkan.

Penelitian awal yang dilakukan Jumarin (2012) menunjukkan bahwa penguasaan efikasi diri siswa sebagian siswa SMA di Kabupaten Kulon progo rendah dan kurang. Hasil wawancara dengan beberapa guru dan observasi -peneliti di SMA 1 Pengasih menunjukkan gejala bahwa sebagian besar siswa memiliki efikasi diri yang rendah. Gejala tersebut antara lain siswa mengeluh apabila diberi tugas yang dirasa agak sulit, siswa sudah merasa tidak bisa sebelum mencoba mengerjakan tugasnya, dalam mengerjakan tugas kurang maksimal, tidak berani bertanya maupun berpendapat karena merasa ragu dengan kemampuannya, kurang meyakini akan kemampuan dirinya, merasa minder dengan temannya yang dianggap lebih pandai, cenderung lebih suka menghindar bila diberi kesempatan mengerjakan tugas.

Bandura (1997) mengemukakan bahwa individu yang mempunyai efikasi diri yang rendah cenderung menyerah ketika dihadapkan pada suatu permasalahan. Selain itu is akan menetapkan target yang lebih rendah dan keyakinan terhadap pencapaian target juga rendah sehingga usaha yang dilakukan lemah, cenderung menghindar bila ada tugas. Dengan demikian, lemahnya efikasi diri dapat membuat siswa enggan melakukan kewajibannya sebagai siswa, yaitu belajar dengan baik. Siswa enggan bersaing mengejar prestasi. Padahal saat ini persaingan semakin ketat, dibutuhkan generasi muda yang unggul. Keunggulan tersebut dapat diperoleh melalui proses belajar yang optimal. Proses belajar yang optimal dapat diraih apabila efikasi diri yang dimiliki siswa cukup

Menurut Bandura (1997) faktor yang dapat mempengaruhi efikasi diri, yaitu mastery experience (pengalaman menyelesaiakan masalah), pengalaman orang lain sebagai model (Vicarious experience), persuasi verbal (verbal persuasion), dan keadaan fisiologis dan emosional individu (emotional arousal). Pajares \& Schunk (Jumarin, 2012) mengemukakan bahwa keluarga, sekolah dan teman sebaya dapat membentuk efikasi diri individu. Berdasar hal-hal tersebut, peneliti mencari bentuk kegiatan yang dapat mempengaruhi efikasi diri. Dengan adanya kegiatan tersebut diharapkan dapat membentuk dan meningkatkan efikasi diri (keyakinan diri) individu agar dapat mengubah persepsi ketidakmampuan terhadap diri sendiri menjadi yakin dan mampu untuk mengorganisasikan dan mengambil tindakan yang dibutuhkan sehingga akhirnya dapat membentuk perilaku yang relevan dan memperoleh hasil seperti yang diharapkan.

Konseling kelompok merupakan suatu upaya pembimbing atau konselor untuk membantu memecahkan masalah-masalah pribadi yang dialami oleh masing-masing anggota kelompok melalui kegiatan kelompok agar tercapai perkembangan optimal (Tohirin, 2009). Konseling kelompok lebih menekankan pada pengembangan diri pribadi, yaitu membantu individu-individu dengan cara mendorong pencapaian tujuan perkembangan dan memfokuskan pada kebutuhan dan kegiatan belajarnya. Perasaan dan hubungan antara anggota sangat ditekankan dalam kelompok. Anggota kelompok akan belajar tentang dirinya dalam hubungannya dengan anggota lain atau orang lain, selain itu dalam konseling kelompok anggota kelompok dapat pula belajar memecahkan masalah berdasarkan masukan dari anggota lain. Asumsi ini menjadi acuan peneliti dalam penelitian ini, sebab konseling kelompok lebih memberikan ruang kepada individu dalam mengambil keputusan, bukan karena dipaksa oleh orang lain akan tetapi keputusan untuk merubah tingkah laku adalah keputusan yang diambil oleh individu karena didukung oleh kesadaran 
yang tinggi yang pada akhirnya menciptakan perubahan tingkah laku siswa.

\section{Kajian Literatur}

\section{Efikasi Diri}

Bandura (1997) mengartikan efikasi diri sebagai keyakinan akan kemampuan individu untuk dapat mengorganisasi dan melaksanakan serangkaian tindakan yang dianggap perlu untuk mencapai suatu hasil yang diinginkan. Efikasi diri merupakan keyakinan yang dipegang seseorang tentang kemampuannya dan juga hasil yang akan is peroleh dari kerja kerasnya yang akan mempengaruhi cara individu berperilaku. Efikasi diri membantu seseorang dalam menentukan pilihan dan usaha untuk maju, kegigihan dan ketekunan yang ditunjukkan dalam menghadapi kesulitan, dan deraj at kecemasan atau ketenangan yang dialami saat individu mempertahankan tugas-tugas dalam kehidupan seseorang.

Bandura (1997) mengemukakan aspekaspek yang terdapat dalam efikasi diri ada tiga, yaitu: pertama tingkat kesulitan (level) yang merupakan kemampuan seseorang untuk menyelesaikan tugas yang tingkat kesulitannya berbeda. Individu dengan efikasi diri yang tinggi akan mempunyai keyakinan yang tinggi tentang kemampuan dalam melakukan suatu tugas. Sebaliknya individu yang memiliki efikasi diri yang rendah akan memiliki keyakinan yang rendah pula tentang kemampuan dirinya. Kedua keluasan/keadaan umum (Generality) merupakan dimensi yang berkaitan dengan luas dan beragamnya bidang tugas yang dihadapi individu. Tugas-tugas perkembangan remaja yang harus dihadapi menurut Havighurst (Diponegoro dan Ru'iya, 2013) antara lain: 1) memperoleh sejumlah norma-norma dan nilai-nilai, 2) belajar memiliki peranan sosial sesuai dengan jenis kelamin masing-masing, 3) menerima kenyataan jasmaniah serta dapat menggunakannya secara efektif dan merasa puas terhadap keadaan tersebut, 4) mencapai kebebasan dari kebergantungan terhadap orangtua dan orang dewasa lainnya, 5) mencapai kebebasan ekonomi, 6) mempersiapkan diri untuk menentukan suatu pekerjaan yang sesuai dengan bakat dan kesanggupannya, 7) memperoleh informasi tentang perkawinan dan mempersiapkannya, 8) mengembangkan kecakapan intelektual dan konsep-konsep tentang kehidupan bermasyarakat, serta 9) memiliki konsep-konsep tingkah laku sosial yang perlu untuk kehidupan bermasyarakat.

Individu yang yakin akan kemampuan dalam menghadapi atau menyelesaikan tugas yang luas dan beragam berarti memiliki efikasi diri yang tinggi. Ciri orang yang efikasi belajarya tinggi adalah disiplin dan mentaati kewajiban, menghargai waktu, toleran terhadap tekanan dan keragaman, produktif, menanggung beban yang beragam.

Sedang yang ketiga adalah ketahanan/kekuatan (Strenght) yang merupakan hal yang berkaitan dengan kekuatan pada keyakinan individu atas kemampuannya. Individu memiliki keyakinan yang kuat dan ketekunan dalam usaha yang akan dicapai meskipun terdapat kesulitan dan rintangan.

Menurut Bandura (1997) perubahan tingkah laku dalam diri individu pada dasarnya adalah perubahan ekspektasi efikasi (efikasi diri). Efikasi diri tersebut dapat diperoleh, diubah, ditingkatkan atau diturunkan, melalui salah satu atau kombinasi dari empat sumber. Empat sumber tersebut adalah: pengalaman menyelesaikan masalah (mastery experience), pengalaman orang lain sebagai model sosial (vicarious experience), persuasi sosial/verbal (verbal persuation/social persuation) dan kondisi fisik dan emosional (physiological and affective states).

\section{Konseling Kelompok}

Konseling kelompok merupakan salah satu teknik di bidang psikologi dalarn memberikan bantuan kepada individu. Gazda, Duncan, \& Meadows (Gazda, 1989) mendefinisikan konseling kelompok sebagai proses interpersonal yang dinamis berfokus pada pikiran sadar dan perilaku, melibatkan fungsi terapi yang permisif, orientasi pada realitas, katarsis, dan saling percaya, peduli, pengertian, penerimaan, dan dukungan. Fungsi Terapi diciptakan dan dipelihara dalam kelompok kecil melalui berbagi hubungan pribadi dengan rekan dalam kelompoknya dan seorang atau beberapa konselor.

Tujuan dari pemberian konseling kelompok adalah untuk membantu individu 
agar mencapai perkembangan yang optimal, individu dapat belajar menumbuhkan dan meningkatkan kemampuannya dalam kelompok tersebut dan/atau memecahkan permasalahan yang dialami oleh individu yang tergabung dalam anggota kelompok agar dapat mengembangkan dirinya sampai batas kemampuannya.

Ada beberapa teknik yang dapat diterapkan dalam pelaksanan konseling kelompok. Tohirin (2009) mengemukakan dua teknik yang dapat digunakan dalam layanan konselig kelompok, yaitu teknik teknik umum (pengembangan dinamika kelompok) dan teknik permainan kelompok.

\section{Metode Penelitian}

Prosedur dalam penelitian ini diawali dengan tahap persiapan, berupa persiapan administrasi, persiapan alat ukur, persiapan kerja sama dan persipan alat eksperimen berupa modul konseling kelompok. Setelah tahap persiapan selanjutnya peneliti melangkah ke tahap pelaksanaan. Dalam tahap pelaksanaan kegiatan yang dilaksanakan adalah pretest, perlakuan dan ' posttest.

Metode penelitian yang digunakan adalah metode penelitian eksperimen (eksperimental research) yang membagi subyek penelitian ke dalam kelompok eksperimen dan kelompok kontrol. Proses penjaringan subyek dalam penelitian ini melalui hasil screening skala efikasi diri yang sudah teruji validitas dan reliabilitasnya sebagai pretest. Selanjutnya peneliti memilih 16 siswa dan memisahkannya menjadi kelompok eksperimen dan kelompok kontrol berdasarkan random asigment yang berarti bahwa setiap subyek memiliki kesempatan yang sama untuk ditempatkan disetiap kondisi perlakuan. Dengan demikian diharapkan dapat diperoleh dua kelompok subyek yang relatif homogen dalam hal efikasi dirinya. Jumlah subyek masingmasing kelompok adalah delapan siswa.

Kelompok eksperimen merupakan kelompok subyek yang mendapatkan perlakuan berupa konseling kelompok sebanyak enam kali pertemuan yang berpedoman pada modul konseling kelompok yang dibuat oleh peneliti. Modul terdiri dari enam topik, yaitu tentang orientasi kegiatan dan kontrak kerja, pemahaman diri, mengenal potensi diri, mengembangkan potensi diri, konsep diri positif, dan pemantapan diri yang dilaksanakan dalam enam kali pertemuan, dan tiap pertemuan berlangsung sekitar 60 90 menit. Kelompok kontrol merupakan kelompok subyek yang tidak mendapatkan perlakuan konseling kelompok. Setelah kelompok eksperimen selesai diberi perlakuan, selanjutnya kedua kelompok diberikan posttest dengan skala yang sama dengan skala pretest yang dimodifikasi dalam tampilannya.

Metode analisis data berupa uji normalitas data, uji homogenitas data dan uji hipotesis hasil penelitian. Uji normalitas diperoleh dari hasil gain pada kedua kelompok penelitian, dengan menggunakan teknik one-sample Kolmogorov-Smirnov test. Uji homogenitas dalam penelitian ini menggunakan uji $\mathrm{F}$ levene statistic. Uji hipotesis penelitian menggunakan statistik parametris, untuk mengetahui pengaruh konseling kelompok terhadap efikasi diri digunakan uji-t independen (independent $t$ test).

\section{Hasil Penelitian dan Pembahasan}

Metode analisis data berupa uji normalitas data, uji homogenitas data dan uji hipotesis hasil penelitian. Hasil dari masing-masing analisis data dapat dikemukakan sebagai berikut:

Tabel 1. Hasil Uji Normalitas

\begin{tabular}{|c|c|c|c|c|}
\hline Variabel & Z hitun & $\begin{array}{c}\mathrm{Z} \\
\text { tabel }\end{array}$ & P & Ket \\
\hline $\begin{array}{c}\text { Gain } \\
\text { Kelompok } \\
\text { kontrol }\end{array}$ & 0,599 & 1,960 & 0,866 & Normal \\
\hline $\begin{array}{c}\text { Gain } \\
\text { Kelompok } \\
\text { eksperimen }\end{array}$ & 0,396 & 196 0' & $\mid 0,998$ & Normal \\
\hline
\end{tabular}

Hasil uji normalitas variabel penelitian menunjukkan bahwa semua gain skor yang diperoleh kelas eksperimen maupun kelas kontrol mempunyai nilai $\mathrm{Z}$ hitung lebih kecil dari $\mathrm{Z}$ tabel dan nilai signifikansi lebih besar dari 0,05 pada $(p>0,05)$. Sehingga dapat disimpulkan bahwa kedua gain yang diperoleh dari kelas eksperimen maupun kelas kontrol berdistribusi normal. 
Tabel 2. Hasil Uji Homogenitas

\begin{tabular}{|c|c|c|c|c|}
\hline Kelompok & F hitung & $\begin{array}{c}\mathrm{F} \\
\text { tabel }\end{array}$ & $\mathrm{P}$ & Ket \\
\hline $\begin{array}{c}\text { Efikasi } \\
\text { Diri }\end{array}$ & 0,201 & 4,54 & 0,661 & $\begin{array}{c}\mathrm{Fa}<\mathrm{Ft}=\mathrm{Ho} \\
\text { mogen }\end{array}$ \\
\hline
\end{tabular}

Hasil uji homogenitas menunjukkan bahwa data efikasi diri pada kelompok eksperimen maupun kelompok kontrol yang diestimasi berdasarkan nilai gain dapat diketahui nilai signifikansi lebih besar dari $5 \%$ ( $\mathrm{p}>0,05)$ dan $\mathrm{F}$ hitung $<\mathrm{F}$ tabel, yang berarti bahwa efikasi kedua kelompok tersebut homogen.

Tabel 3.

\section{Hasil Independent t-Test Gain Efikasi diri}

\begin{tabular}{|c|c|c|c|c|c|}
\hline $\begin{array}{c}\text { Sumber } \\
\text { Data }\end{array}$ & Rerata & SD & $\begin{array}{c}\mathrm{t} \\
\text { hitung }\end{array}$ & $\mathrm{t}$ tabel & $\mathrm{p}$ \\
\hline $\begin{array}{c}\text { Gain } \\
\text { Kontrol }\end{array}$ & 1,2500 & 2,6049 & & & \\
\hline $\begin{array}{c}\text { Gain } \\
\text { Eksperime } \\
\mathrm{n}\end{array}$ & 9,8750 & 3,1367 & & & \\
6 & & 2,983 & 2,306 & 0,000 \\
\hline
\end{tabular}

Berdasarkan hasil uji hipotesis yang menggunakan independent-t test diketahui bahwa rata-rata gain skor efikasi diri pada kelompok eksperimen adalah 9,8750 dengan standar deviasi 3,13676, sedangkan rata-rata gain skor efikasi din pada kelompok eksperimen adalah 1,2500 dengan standar deviasi 2,60494. Hasil analisis memperoleh nilai signifikansi sebesar 0,000 . Nilai signikansi lebih kecil dari $0,01 \quad(\mathrm{p}<0,01)$, hasil ini menunjukkan ada perbedaan yang signifikan antara gain skor efikasi din pada Konseling kelompok lebih memberikan ruang kepada individu dalam mengambil keputusan bukan kelompok eksperimen dan kontrol.

Hasil penelitian ini menunjukkan bahwa ada pengaruh konseling kelompok terhadap efikasi din siswa kelas X SMA N 1 Pengasih Kulon Progo. Konseling kelompok dapat meningkatkan efikasi diri pada kelompok eksperimen. Hal ini ditunjukkan dengan uji independen $t$ test gain skor efikasi diri pada kelompok kontrol dan eksperimen. Hasil pengujian menunjukkan bahwa diperoleh nilai signifikansi 0,000 yang lebih kecil dari 0,01 sehingga Ho ditolak. Artinya ada pengaruh efikasi diri pada siswa sebelum (pretest) dfflt. sesudah (postest) dengan diberi konseling kelompok.

Penelitian ini lebih menekankan pengaruh perlakuan yang berupa konseling kelompok. Efikasi diri dapat ditingkatkan melalui belajar perilaku barn yaitu perilaku keyakinan diri. Perilaku ini dipelajari dengan cara mengobservasi perilaku orang lain dan berlatih untuk meniru. Lingkungan yang kondusif memberikan kesempatan untuk mengekpresikan ide-ide dan perasaan memberi, menerima, memberikan dukungan dan bantuan untuk orang lain, menerima dan memberi umpan balik akan berarti bagi individu. Dengan adanya saling komunikasi diharapkan individu dapat memiliki efikasi diri yang positif karena dipaksa oleh orang lain akan tetapi keputusan untuk merubah tingkah laku adalah keputusan yang diambil oleh individu kerena didukung oleh kesadaran yang tinggi yang pada akhirnya menciptakan perubahan tingkah laku siswa. Anggota kelompok dapat memperoleh umpan balik dari konselor dan anggota lain, sehingga tiap anggota akan dapat langsung berlatih perilaku bare dalam komunitas dan hasil perilaku tersebut dapat diamati dan dievaluasi balik oleh konselor, anggota lain maupun dirinya sendiri. Selain itu juga kesempatan untuk saling memberi dukungan dan bantuan akan dapat meningkatkan efikasi dirinya.

Enam topik yang diberikan pada pelaksanaan konseling kelompok dalam penelitian ini, yaitu:

a. Orientasi, ice breaking dan kontrak kegiatan.

Tujuan pemberian materi dalam tahap ini adalah untuk pengenalan terhadap pelaksanaan konseling kelompok. Pada tahap ini diharapkan mampu menumbuhkan rasa kepercayaan siswa terhadap konselor dan membangun suasana konseling yang aman, akrab, dan harmonis. Hasil kegiatan awal ini dapat digunakan sebagai landasan dimulainya pengumpulan calon anggota kelompok dalam rangka kegiatan konseling kelompok yang direncanakan. Jadi pada tahap ini merupakan tahap pengenalan, pembinaan hubungan baik, tahap pelibatan diri atau tahap memasukkan 
diri ke dalam kehidupan suatu kelompok. Pada tahap ini umumnya para anggota saling memperkenalkan diri, membina hubungan baik dan juga mengungkapkan tujuan dan harapan yang ingin dicapai oleh masing-masing, sebagian maupun seluruh anggota kelompok.

b. Pemahaman diri

Pada pembahasan topik inidiharapkan siswa mampu mengenal dirinya serta mampu mengenal kelebihan dan kekurangannya. Pengenalan diri ini merupakan tahap awal untuk pemahaman tentang kemampuan yang ada pada diri subyek.

c. Mengenal potensi diri

Pemberian materi pada tahap ini bertujuan untuk mengarahkan pada siswa untuk mengenal potensi sendiri. Eggen dan Kauchack (1997) menyatakan bahwa pembelajaran yang baik adalah proses yang mengundang siswa untuk melihat dirinya sebagai orang yang mampu, memiliki nilai, dan mengarahkan diri sendiri, dan memberi semangat pada mereka untuk berbuat sesuai dengan persepsi dirinya tersebut. Penilaian seseorang terhadap kemampuan diri yang dimiliki mempunyai peran yang sangat penting dalam proses perkembangan individu, khususnya terkait dengan kemampuan dalam menyelesaikan masalah yang dihadapi. Feist \& Feist (2002) menyatakan bahwa efikasi diri merupakan keyakinan individu bahwa mereka memiliki kemampuan dalam mengadakan kontrol terhadap pekerjaan mereka terhadap lingkungan mereka sendiri

d. Mengembangkan potensi diri

Materi ini bertujuan agar siswa
mempunyai gambaran tentang
pengelolaan potensi diri dan
merencanakan pengembangan potensi
diri secara positif. Bandura (1997)
mengemukakan bahwa individu yang
mempunyai efikasi diri yang tinggi
mempunyai keyakinan bahwa mereka
mampu berperilaku tertentu untuk dapat
mencapai hasil yang diinginkan. Mereka
juga lebih giat dan tekun dalam berusaha
dan mengatasi kesulitan serta mampu
menggerakkan tenaga yang besar untuk
mengatasi tantangan. Selain itu individu
yg mempunyai efikasi diri tinggi akan

menetapkan target lebih tinggi dengan usaha keras untuk mencapainya.

e. Konsep diri positif

Konsep diri positif ini bertujuan untuk memberikan pengarahan kepada siswa agar bersikap obyektif dalam mengenali diri sendiri, mampu menghargai diri sendiri, serta mampu berpikir positif dan rasional tentang diri dan lingkungannya. Apabila individu memiliki pikiran positif tentang dirinya, maka individu tersebut akan mempunyai konsep diri yang positif yang selanjutnya dapat meningkatkan efikasi dirinya. Hal ini sesuai juga dengan hasil penelitian Dwitantyanov, dkk (2010) yang membuktikan bahwa pelatihan berpikir positif mempunyai pengaruh dalam meningkatkan efikasi diri. Hasil penelitian Pambudi dan Wijayanti (2012) menyimpulkan bahwa apabila konsep diri baik maka prestasi belajamya juga akan baik. Dalam penelitian ini diharapkan siswa memiliki efikasi diri yang tinggi sehingga siswa juga dapat memiliki prestasi belajar yang baik.

f. Pemantapan diri

Tahap terakhir dalam konseling kelompok adalah pemantapan diri. Hal ini bertujuan agar siswa mampu merencanakan perilaku masa depan kearah yang lebih baik dan memiliki kemampuan yang dimiliki dirinya.

Melalui konseling kelompok siswa dapat mengurangi tekanan mental yang ada pada dirinya seperti stress dan kecemasan, karena melalui dinamika kelompok dibangun suasana kejiwaan yang sehat, antara lain berkenaan dengan spontanitas, gembira, rileks, dan kebersamaan.

\section{Kesimpulan}

Berdasarkan hasil pengukuran, analisis data dan pembahasan variabel penelitian, maka peneliti mengambil kesimpulan bahwa ada pengaruh konseling kelompok terhadap efikasi diri. Hasil ini berdasarkan uji independen $\mathrm{t}$ test menggunakan gain skor yang menunjukkan bahwa terdapat perbedaan yang signifikan antara gain skor kelompok eksperimen dan kelompok kontrol dengan rerata gain skor kelompok 
eksperimen lebih tinggi dan kelompok kontrol.

Rekomendasi penelitian ditujukan kepada berbagai pihak stakeholder, khususnya guru bimbingan dan konseling, siswa, dan peneliti selanjutnya.

\section{Referensi}

Bandura, A. (1997). Self-efficacy the exercise of control. New York: W.H. Freeman and Company.

Caroll, A., Houghton, S., Wood, R., Unsworth, K., Hattie, J., Gordon, L., \& Bower, J. (2009). Self-efficacy and Academic Achievement in Australian Hight School Student: The Mediating Effects of Academic Aspirations and Delinquency. Journal of Adolescence. 32:797-817.

Diponegoro, A.M., dan Ru'iya, S. (2013). Peran Religiusitas Islami dan Kesejahteraan Subyektif Terhadap Pemaafan Remaja Siswa Madrasah Aliyah Negeri III Yogyakarta. PSIKOPEDAGOGIA Jurnal Bimbingan dan Konseling, 2 (1): 55-69.

http://www.sciencedirect.com/science/articl e/pii/S 014019710800122X 31Mei 2011.

Eggen, P., \& Kauchack, D. (1997). Educational Psychology: Windows on Classroom. New Jersey: prentic Hall Inc.

Gazda, G.M. 1989. Group Counseling a Developmental Approach Fourth edition. Boston: Allyn and Bacon.

Jumarin, M. (2012). Model Bimbingan Konseling Manajemen-Diri (Bkmd) untuk Meningkatkan Kompetensi dan Efikasi Diri Dalam Belajar. Disertasi. (tidak diterbitkan). Bandung: Pasca Sarjana Universitas Pendidikan Indonesia.

Surya, M. (2004). Psikologi Pembelajaran dan Pengajaran. Bandung: Pustaka Bani Quraisy.

Susilowati, A. (2009). Hubungan antara efikasi din dengan prestasi belajar pada siswa SMA Negeri 8 Surakarta. Skripsi tidak diterbitkan. Surakarta: Fakultas Psikologi Universitas Muhammadiyah Surakarta.

Tohirin. (2009). Bimbingan dan Konseling di Sekolah dan Madrasah (Berbasis integrasi). Jakarta: Raja Grafindo Persada.

Zimmerman, B.J. (2009). Self-Efficacy in Academic, in Self-Efficacy in Changing Societies (Editor Bandura). Stanford University. 